\title{
Front Matter: Volume 8515
}

, "Front Matter: Volume 8515," Proc. SPIE 8515, Imaging Spectrometry XVII, 851501 (15 October 2012); doi: 10.1117/12.2008668

SPIE Event: SPIE Optical Engineering + Applications, 2012, San Diego, California, SPIE. United States 


\section{PROCEEDINGS OF SPIE}

\section{Imaging Spectrometry XVII}

Sylvia S. Shen

Paul E. Lewis

Editors

13-14 August 2012

San Diego, California, United States

Sponsored and Published by

SPIE 
The papers included in this volume were part of the technical conference cited on the cover and title page. Papers were selected and subject to review by the editors and conference program committee. Some conference presentations may not be available for publication. The papers published in these proceedings reflect the work and thoughts of the authors and are published herein as submitted. The publisher is not responsible for the validity of the information or for any outcomes resulting from reliance thereon.

Please use the following format to cite material from this book:

Author(s), "Title of Paper," in Imaging Spectrometry XVII, edited by Sylvia S. Shen, Paul E. Lewis, Proceedings of SPIE Vol. 8515 (SPIE, Bellingham, WA, 2012) Article CID Number.

ISSN: 0277-786X

ISBN: 9780819492326

Published by

SPIE

P.O. Box 10, Bellingham, Washington 98227-0010 USA

Telephone +1 3606763290 (Pacific Time) · Fax +1 3606471445

SPIE.org

Copyright @ 2012, Society of Photo-Optical Instrumentation Engineers.

Copying of material in this book for internal or personal use, or for the internal or personal use of specific clients, beyond the fair use provisions granted by the U.S. Copyright Law is authorized by SPIE subject to payment of copying fees. The Transactional Reporting Service base fee for this volume is $\$ 18.00$ per article (or portion thereof), which should be paid directly to the Copyright Clearance Center (CCC), 222 Rosewood Drive, Danvers, MA 01923. Payment may also be made electronically through CCC Online at copyright.com. Other copying for republication, resale, advertising or promotion, or any form of systematic or multiple reproduction of any material in this book is prohibited except with permission in writing from the publisher. The CCC fee code is 0277-786X/12/\$18.00.

Printed in the United States of America.

Publication of record for individual papers is online in the SPIE Digital Library.

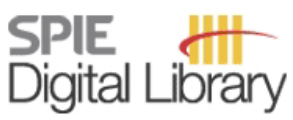

SPIEDigitalLibrary.org

Paper Numbering: Proceedings of SPIE follow an e-First publication model, with papers published first online and then in print and on CD-ROM. Papers are published as they are submitted and meet publication criteria. A unique, consistent, permanent citation identifier (CID) number is assigned to each article at the time of the first publication. Utilization of CIDs allows articles to be fully citable as soon as they are published online, and connects the same identifier to all online, print, and electronic versions of the publication. SPIE uses a six-digit CID article numbering system in which:

- The first four digits correspond to the SPIE volume number.

- The last two digits indicate publication order within the volume using a Base 36 numbering

system employing both numerals and letters. These two-number sets start with 00, 01, 02, 03, 04, $05,06,07,08,09,0 A, 0 B \ldots 0 Z$, followed by 10-1Z, 20-2Z, etc.

The CID Number appears on each page of the manuscript. The complete citation is used on the first page, and an abbreviated version on subsequent pages. Numbers in the index correspond to the last two digits of the six-digit CID Number. 


\section{Contents}

vii Conference Committee

SESSION 1 ADVANCEMENTS IN SPECTROMETER SYSTEMS I

851503 Detection of chemical pollutants by passive LWIR hyperspectral imaging (Invited Paper) [8515-2]

H. Lavoie, J.-M. Thériault, F. Bouffard, E. Puckrin, D. Dubé, Defence Research and

Development Canada, Valcartier (Canada)

851505 Modular hyperspectral imager enables multiple research applications [8515-4]

N. Hô, F. Prel, L. Moreau, ABB Inc. (Canada); H. Lavoie, F. Bouffard, D. Dubé, J.-M. Thériault, Defence Research and Development Canada, Valcartier (Canada); C. Vallières, C. Roy, ABB Inc. (Canada)

\section{SESSION 2 ATMOSPHERIC AND ENVIRONMENTAL SPECTROSCOPY I}

851506 The Geostationary Fourier Transform Spectrometer [8515-5]

R. Key, S. Sander, A. Eldering, J.-F. Blavier, D. Bekker, K. Manatt, D. Rider, Y.-H. Wu, Jet Propulsion Lab. (United States)

851507 Global and regional seasonal variability of mid-tropospheric $\mathrm{CO}_{2}$ as measured by the Atmospheric Infrared Sounder (AIRS) [8515-7]

T. S. Pagano, E. T. Olsen, H. Nguyen, Jet Propulsion Lab. (United States)

\section{SESSION 3 SPECTRAL METHODOLOGIES AND APPLICATIONS I}

8515 OA Algorithms for the detection and mapping of wildfires in SPOT 4 and 5 imagery [8515-10] B. Bagnall, E. Sharghi, H. Buck, Space and Naval Warfare Ctr. Pacific (United States)

8515 OB Automatic swimming pool identification for fire suppression [8515-11]

B. Fitzsimmons, H. Buck, Space and Naval Warfare Ctr. Pacific (United States)

$85150 \mathrm{C}$ Low-cost near-real-time automated geo-registration of commercial-off-the-shelf (COTS) digital camera and spectrometer sensor data with camera link standard data streams [8515-12]

T. Bratcher, lonetrics, Inc. (United States); R. Kroutil, State of New Mexico (United States); P. E. Lewis, National Geospatial-Intelligence Agency (United States); D. Miller, TASC, Inc. (United States); S. Shen, The Aerospace Corp. (United States); M. Thomas, U.S.

Environmental Protection Agency (United States)

8515 OD Detection of abandoned mines/caves using airborne LWIR hyperspectral data [8515-13] S. S. Shen, K. A. Roettiger, The Aerospace Corp. (United States) 
$8515 \mathrm{OE} \quad$ Latest developments in active remote sensing at INO [8515-14]

F. Babin, R. Forest, B. Bourliaguet, D. Cantin, P. Cottin, O. Pancrati, S. Turbide, Institut National d'Optique (Canada); S. Lambert-Girard, Ctr. d'Optique Photonique et Laser, Univ. Laval (Canada); F. Cayer, D. Lemieux, J.-F. Cormier, F. Châteauneuf, Institut National d'Optique (Canada)

8515 OF Portable Remote Imaging Spectrometer (PRISM): laboratory and field calibration [8515-16] P. Mouroulis, B. Van Gorp, R. O. Green, M. Eastwood, Jet Propulsion Lab. (United States); J. Boardman, Analytical Imaging and Geophysics LLC (United States); B. S. Richardson, J. I. Rodriguez, E. Urquiza, B. D. Franklin, Jet Propulsion Lab. (United States); B.-C. Gao, U.S. Naval Research Lab. (United States)

$85150 G$ Ultra-compact Imaging Spectrometer (UCIS) for in-situ planetary mineralogy: laboratory and field calibration [8515-17]

B. Van Gorp, P. Mouroulis, R. O. Green, J. I. Rodriguez, D. Blaney, D. W. Wilson, R. G. Sellar, B. S. Richardson, Jet Propulsion Lab. (United States)

$8515 \mathrm{OH} \quad$ Research on imaging spectrometer using LC-based tunable filter [8515-18] Z. Shen, J. Li, L. Huang, F. Luo, Y. Luo, D. Zhang, Y. Long, Institute of Fluid Physics (China)

\section{SESSION 5 SPECTRAL DATA ANALYSIS TECHNIQUES}

8515 ol False-alarm characterization in hyperspectral gas-detection applications [8515-19] R. S. DiPietro, MIT Lincoln Lab. (United States); E. Truslow, Northeastern Univ. (United States); D. G. Manolakis, S. E. Golowich, R. B. Lockwood, MIT Lincoln Lab. (United States)

$85150 \mathrm{~J}$ Range-invariant anomaly detection applied to imaging Fourier transform spectrometry data [8515-20]

C. Borel, Air Force Institute of Technology (United States); D. Rosario, U.S. Army Research Lab. (United States); J. Romano, U.S. Army Armament RDEC (United States)

8515 OK Background suppression and feature based spectroscopy methods for sub-pixel material identification [8515-21]

R. S. Rand, National Geospatial-Intelligence Agency (United States); J. M. Grossmann, The MITRE Corp. (United States); R. N. Clark, E. Livo, U.S. Geological Survey (United States);

J. T. Parr, BBN Technologies (United States)

$8515 \mathrm{OL} \quad$ Endmember extraction using the physics-based multi-mixture pixel model [8515-22] R. Close, U.S. Army RDECOM CERDEC NVESD (United States); P. Gader, Univ. of Florida (United States); A. Zare, Univ. of Missouri (United States); J. Wilson, D. Dranishnikov, Univ. of Florida (United States)

$85150 \mathrm{M}$ Linear unmixing-based feature extraction for hyperspectral data in a high performance computing environment [8515-23]

S. A. Robila, Montclair State Univ. (United States) 
8515 ON Conceptual optical design and system engineering of the CLARREO/RS (reflected solar) instrument suite [8515-24]

P. L. Thompson, P. C. Hill, NASA Goddard Space Flight Ctr. (United States)

851500 The point response functions of CERES instruments aboard the Terra and Aqua spacecrafts over the mission-to-date [8515-25]

J. L. Daniels, S. Thomas, G. L. Smith, Science Systems Applications, Inc. (United States);

K. J. Priestley, NASA Langley Research Ctr. (United States)

8515 OP Observing system simulation experiments to assess the impact of remotely sensed data on hurricane prediction [8515-26]

R. Atlas, National Oceanic and Atmospheric Administration (United States)

$85150 Q \quad$ Exploring new polarimetric techniques using unconventionally polarized sources [8515-27]

B. G. Zimmerman, P. Adamson, T. G. Brown, The Institute of Optics, Univ. of Rochester

(United States); J. Vanderlei Martins, Univ. of Maryland, Baltimore County (United States)

\section{SESSION 7 SPECTRAL METHODOLOGIES AND APPLICATIONS II}

8515 OS Self-adaptive road tracking in hyperspectral data for C-IED [8515-31]

H. Schilling, W. Gross, W. Middelmann, Fraunhofer Institute of Optronics, System

Technologies and Image Exploitation (Germany)

\section{POSTER SESSION}

$85150 \mathrm{~V}$ Analytical design of a hyper-spectral imaging spectrometer utilizing a convex grating [8515-32]

S. H. Kim, KAIST (Korea, Republic of) and Samsung Thales (Korea, Republic of); H. J. Kong,

H. Ku, KAIST (Korea, Republic of); J. H. Lee, Kongju National Univ. (Korea, Republic of)

Author Index 
Proc. of SPIE Vol. $8515851501-6$

Downloaded From: https://www.spiedigitallibrary.org/conference-proceedings-of-spie on 26 Apr 2023 Terms of Use: https://www.spiedigitallibrary.org/terms-of-use 


\section{Conference Committee}

Program Track Chair

Allen H.-L. Huang, University of Wisconsin-Madison (United States)

Conference Chairs

Sylvia S. Shen, The Aerospace Corporation (United States)

Paul E. Lewis, National Geospatial-Intelligence Agency (United States)

Conference Program Committee

Christoph C. Borel, Air Force Institute of Technology (United States)

Chein-I Chang, University of Maryland, Baltimore County (United States)

François Châteauneuf, Institut National d'Optique (Canada)

Thomas Cooley, Air Force Research Laboratory (United States)

Eustace L. Dereniak, College of Optical Sciences, The University of Arizona (United States)

Kevin C. Gross, Air Force Institute of Technology (United States)

Robert T. Kroutil, Dynamac Corporation (United States)

Pantazis Mouroulis, Jet Propulsion Laboratory (United States)

Thomas S. Pagano, Jet Propulsion Laboratory (United States)

Luc Rochette, LR Tech (Canada)

John R. Schott, Rochester Institute of Technology (United States)

John F. Silny, Raytheon Space \& Airborne Systems (United States)

\section{Session Chairs}

1 Advancements in Spectrometer Systems I

Paul E. Lewis, National Geospatial-Intelligence Agency (United States)

2 Atmospheric and Environmental Spectroscopy I

Thomas S. Pagano, Jet Propulsion Laboratory (United States)

3 Spectral Methodologies and Applications I

Kevin C. Gross, Air Force Institute of Technology (United States)

4 Advancements in Spectrometer Systems II

Kevin C. Gross, Air Force Institute of Technology (United States) 
5 Spectral Data Analysis Techniques

Christoph C. Borel, Air Force Institute of Technology (United States)

6 Atmospheric and Environmental Spectroscopy II

Paul E. Lewis, National Geospatial-Intelligence Agency (United States)

7 Spectral Methodologies and Applications II

Sylvia S. Shen, The Aerospace Corporation (United States) 